\title{
Distribution extension of Alopoglossus buckleyi (O'Shaughnessy, 1881) (Squamata: Alopoglossidae)
}

\author{
A. A. A. Pereira (DD, V. Guerra $^{a *}$ (D), M. S. Barbosa ${ }^{a}$ (D) and F. Corrêa ${ }^{b}$ \\ aUniversidade Federal do Acre - UFAC, Centro de Ciências Biológicas e da Natureza, Rio Branco, Acre, Brasil

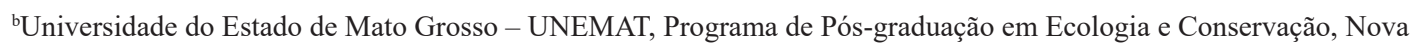 \\ Xavantina, MT, Brasil \\ *e-mail: vinicius.guerrabatista@gmail.com
}

Received: November 19, 2019 - Accepted: February 26, 2020 - Distributed: August 31, 2021

(With 1 figure)

The family Alopoglossidae is composed by the genus Alopoglossus Boulenger, 1885 and Ptychoglossus Boulenger, 1890 , which is distributed from Costa Rica to northern South America (Köhler et al., 2012; Peloso and Morales, 2017; Ribeiro-Junior and Amaral, 2017). A recent study using morphological and molecular dataset increased the number of species in the genus Alopoglossus from nine to fourteen (Ribeiro-Júnior et al. 2020): Alopoglossus amazonius Ruthven, 1924, A. andeanus Ruibal, 1952, A. angulatus (Linnaeus, 1758), A. atriventris Duellman, 1973, A. avilapiresae Ribeiro-Júnior, Choueri, Lobos, Venegas, Torres-Carvajal \& Werneck, 2020, A. buckleyi (O’Shaughnessy, 1881), A. carinicaudatus (Cope, 1876), A. collii Ribeiro-Júnior, Choueri, Lobos, Venegas, Torres-Carvajal \& Werneck, 2020, A. copii Boulenger, 1885, A. embera Peloso \& Morales, 2017, A. festae Peracca, 1904, A. lehmanni Ayala \& Harris, 1984, A. meloi Ribeiro-Júnior (2018), and $A$. viridiceps Torres-Carvajal \& Lobos, 2014. Alopoglossus buckleyi is a terrestrial and diurnal lizard species, mainly found among leaf litter, in shaded or partially shaded spots (Ávila-Pires, 1995). It is distributed in Brazil, Colombia, Ecuador, and Peru (Ribeiro-Junior and Amaral, 2017; Ribeiro-Júnior et al., 2020). Here, we present a new record of this species in the State of Acre, Brazil, extending its distribution to the east.

On September 2018 an individual of Alopoglossus buckleyi (Figure 1) was captured in a pitfall trap at the Cazumbá-Iracema Extractive Reserve in the State of Acre, Brazil (0907'50.0”S, 6856'17.1'W, 557 a.s.1.). The sampled area is composed of secondary forest, which has already been deforested and is now in a state of regeneration. The species was identified using the taxonomic key proposed by Ávila-Pires (1995) and Köhler et al. (2012). Alopoglossus buckleyi differs from most species of the genus by presenting dorsal scales rhomboidal or lanceolate, in oblique and transverse rows, and scales on side of neck small and granular; and differs from $A$. atriventris (most apparently related species) by presenting smooth ventral scales. The specimen was euthanized with lidocaine, fixed in a solution of $10 \%$ formalin, preserved in a $70 \%$ ethanol solution and housed in the Herpetological Collection of the Universidade Federal do Acre, Rio Branco Municipality, State of Acre, Brazil.

This is the second record of Alopoglossus buckleyi for the state of Acre, expanding the distribution to $350 \mathrm{~km}$ southeast of the previous record (Bernarde et al., 2011). In one year of sampling in the area, only one individual was found, which may be a result of the cryptic behavior and low population density in the locality. Although this species is classified as Least Concern by the IUNC, high frequency of fires and deforestation caused by logging and cattle raising in the Amazon, which intensify the natural fragmentation of its habitat (Malhi et al., 2008), could potentially affect the populations of this species.

Although knowledge on the taxonomic status of Alopoglossus has increased in recent years (Goicoechea et al., 2016; Ribeiro-Junior et al., 2020), many species still lack important information about natural history and distribution, which increases the need for further studies. This new record highlights our lack of knowledge on A. buckleyi, which is the result of poor sampling in many areas of the Amazon (Ribeiro-Júnior and Amaral, 2016). Since the distribution of Alopoglossidae species encompasses two or more areas of endemism (Ribeiro-Junior and Amaral, 2017), systematic surveys should be conducted to improve our understanding of the distribution of the species and in this family, as well as other of the Amazonian reptile species. 

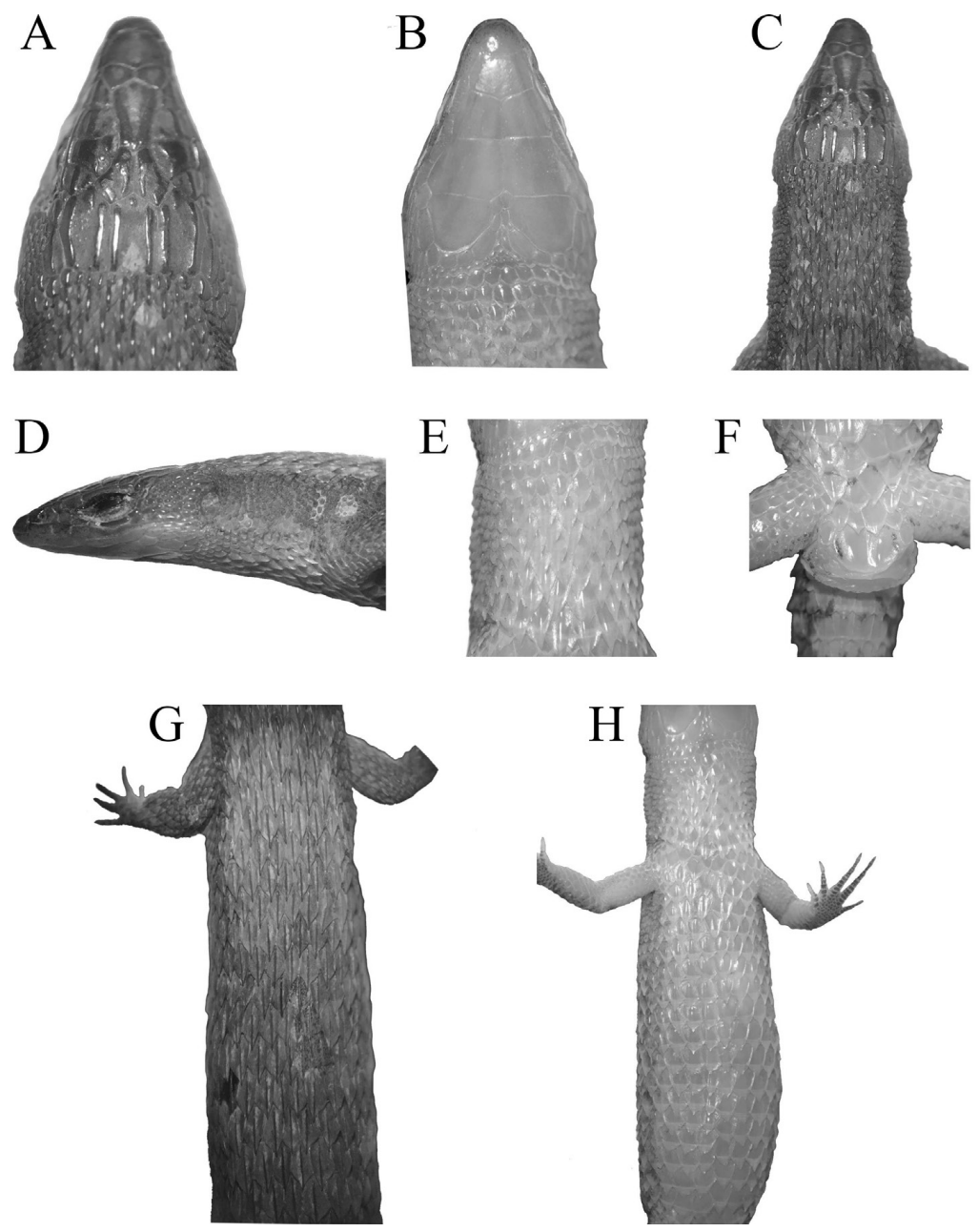

Figure 1. Individual of Alopoglossus buckley collected at Cazumbá-Iracema Extractive Reserve in the State of Acre, Brazil. (A) Dorsal and (B) ventral views of the head, (C) dorsal, (D) lateral and (E) ventral views of the neck, (F) ventral view of the cloaca, $(\mathrm{G})$ dorsal and $(\mathrm{H})$ ventral views of the dorsum.

\section{Acknowledgements}

Allana A. A. Pereira thanks the Coordenação de Aperfeiçoamento de Pessoal de Nível Superior (CAPES) for the Master's scholarship. We thank especially Tereza Avila-Pires for her help in identifying the species. We would also like to thank M.A. Ribeiro-Júnior and an anonymous reviewer for their important contributions to improving the quality of this study. Surveys were conducted under the collection license emitted by the Sistema de Autorização e Informação em Biodiversidade - SISBIO (No. 63621).

\section{References}

ÁVILA-PIRES, T.C.S., 1995. Lizards of Brazilian Amazonia (Reptilia: squamata). Zoologische Verhandelingen Leiden, vol. 299, no. 1, pp. 1-706.

BERNARDE, P.S., MACHADO, R.A. and TURCI, L.C.B., 2011. Herpetofauna da área do Igarapé Esperança na Reserva Extrativista Riozinho da Liberdade, Acre-Brasil. Biota Neotropica, vol. 11, no. 3, pp. 117-144. http://dx.doi.org/10.1590/S167606032011000300010 .

GOICOECHEA, N., FROST, D.R., DE LA RIVA, I., PELLEGRINO, K.C.M., SITES JUNIOR, J., RODRIGUES, M.T. and PADIAL, J.M., 2016. Molecular systematics of teioid lizards (Teioidea/ Gymnophthalmoidea: Squamata) based on the analysis of 48 loci under tree-alignment and similarity alignment. Cladistics, vol. 32, no. 6, pp. 624-671. http://dx.doi.org/10.1111/cla.12150.

KÖHLER, G., DIETHERT, H.H. and VESELY, M., 2012. A contribution to the knowledge of the lizard genus Alopoglossus (Squamata: gymnophthalmidae). Herpetological Monograph, vol. 26 , no. 1, pp. 173-188. http://dx.doi.org/10.1655/ HERPMONOGRAPHS-D-10-00011.1.

MALHI, Y., ROBERTS, J.T., BETTS, R.A., KILLEEN, T.J., LI, W. and NOBRE, C.A., 2008. Climate change, deforestation, and the fate of the Amazon. Science, vol. 319, no. 5860, pp. 169-172. http://dx.doi.org/10.1126/science.1146961. PMid:18048654.

PELOSO, P.L.V. and MORALES, C.H., 2017. Description of a new species of Alopoglossus Boulenger, 1885 from Western Colombia (Gymnophthalmoidea). South American Journal of 
Herpetology, vol. 12, no. 2, pp. 89-98. http://dx.doi.org/10.2994/ SAJH-D-16-00059.1.

RIBEIRO-JÚNIOR, M.A., 2018. A new species of Alopoglossus lizard (Squamata, Alopoglossidae) from the Southern Guiana Shield, northeastern Amazonia, with remarks on diagnostic characters to the genus. Zootaxa, vol. 4422, no. 1, pp. 25-40. http://dx.doi. org/10.11646/zootaxa.4422.1.2. PMid:30313510.

RIBEIRO-JÚNIOR, M.A. and AMARAL, S., 2016. Diversity, distribution, and conservation of lizards (Reptilia: Squamata) in the Brazilian Amazonia. Neotropical Biodiversity, vol. 2, no. 1, pp. 195-421. http://dx.doi.org/10.1080/23766808.2016.1236769.
RIBEIRO-JÚNIOR, M.A. and AMARAL, S., 2017. Catalogue of distribution of lizards (Reptilia: Squamata) from the Brazilian Amazonia. IV. Alopoglossidae, Gymnophthalmidae. Zootaxa, vol. 4269, no. 2, pp. 151-196. http://dx.doi.org/10.11646/ zootaxa.4269.2.1. PMid:28610330.

RIBEIRO-JÚNIOR, M.A., CHOUERI, E., LOBOS, S., VENEGAS, P., TORRES-CARVAJAL, O. and WERNECK, F., 2020. Eight in one: morphological and molecular analyses reveal cryptic diversity in Amazonian alopoglossid lizards (Squamata: Gymnophthalmoidea). Zoological Journal of the Linnean Society. In press. http://dx.doi.org/10.1093/zoolinnean/zlz155. 